\title{
Blue Wavelengths from LED Lighting Increase Nutritionally Important Metabolites in Specialty Crops
}

\author{
Dean A. Kopsell ${ }^{1,2}$ and Carl E. Sams ${ }^{1}$ \\ Plant Sciences Department, The University of Tennessee, Knoxville, TN 37996 \\ Robert C. Morrow \\ Orbital Technologies Corporation, Madison, WI 53717 \\ Additional index words. carotenoid, chlorophyll, glucosinolate, light-emitting diode, mineral
}

\begin{abstract}
Light is one of the most important environmental stimuli impacting plant growth and development. Plants have evolved specialized pigment-protein complexes, commonly referred to as photoreceptors, to capture light energy to drive photosynthetic processes, as well as to respond to changes in light quality and quantity. Blue light can act as a powerful environmental signal regulating phototropisms, suppression of stem elongation, chloroplast movements, stomatal regulation, and cell membrane transport activity. An emerging application of light-emitting diode (LED) technology is for horticultural plant production in controlled environments. Work by our research group is measuring important plant responses to different wavelengths of light from LEDs. We have demonstrated positive impacts of blue wavelengths on primary and secondary metabolism in microgreen and baby leafy green brassica crops. Results show significant increases in shoot tissue pigments, glucosinolates, and essential mineral elements following exposure to higher percentages of blue wavelengths from LED lighting. The perception of energy-rich blue light by specialized plant photoreceptors appears to trigger a cascade of metabolic responses, which is supported by current research showing stimulation of primary and secondary metabolite biosynthesis following exposure to blue wavelengths. Management of the light environment may be a viable means to improve concentrations of nutritionally important primary and secondary metabolites in specialty vegetable crops.
\end{abstract}

Illumination is a powerful environmental stimulus impacting a wide range of plant metabolic processes. Plant species have evolved photoreceptors to sense the light environment and adjust to changing environmental conditions through modulation of cellular processes (Smith, 1982). Unique plant photoreceptors respond to changing light quality and quantity through developmental and physiological responses commonly referred to as photomorphogenesis (Christie, 2007). Photosynthetically active radiation is energy associated with wavelengths of visible light (400-700 nm) predominately absorbed by leaf tissues. Photochemistry in plants is initiated by absorbed quanta, which differ in quantum energy level and absorption capacity of photosynthetically active pigments based on wavelength (McCree, 1973). Thus, the spectral distribution of light sources in plant production will determine photomorphogenic responses. LEDs now provide the option of selecting

Received for publication 26 Nov. 2014. Accepted for publication 9 Jan. 2015.

The cost of publishing this paper was defrayed in part by the payment of page charges. Under postal regulations, this paper therefore must be hereby marked advertisement solely to indicate this fact. Support provided by the Small Business Innovation Research program of the U.S. Department of Agriculture, grant number 2012-33610-19526.

Any opinions, findings, conclusions, or recommendations expressed in this publication are those of the author(s) and do not necessarily reflect the views of the U.S. Department of Agriculture.

This paper was presented as part of the colloquium "The Importance of Light Quality for High Value Plant Products", during the ASHS Annual Conference, 28-31 July 2014, Orlando, FL.

${ }^{1}$ Professor

${ }^{2}$ Corresponding author. E-mail: dkopsell@utk.edu. specific wavelengths to complement photoreceptor pigments for targeted plant physiological responses (Massa et al., 2008; Morrow, 2008).

Maximum light absorption by chlorophyll pigments and quantum yield of photosynthesis occur primarily in the blue and red regions of the visible light spectrum (McCree, 1972). Plants have evolved other specialized photoreceptors to regulate responses to these physiologically important wavelengths. Phytochromes are primarily red-light photoreceptors and distinguish between red and far red wavelengths to control physiological responses such as seed germination and flowering (Chaves et al., 2011; Fraikin et al., 2013; Vierstra and Zhang, 2011). Cryptochromes, phototropins, and F-box proteins (a specific structural motif associated with signal transduction and regulation of the cell cycle) are blue-light receptors responding to blue/ ultraviolet (UV) light wavelengths. Cryptochromes trigger signaling molecules that regulate responses such as circadian rhythms and stem elongation, whereas phototropins control chloroplastic movements to maximize absorption of light (Briggs and Christie, 2002; Christie, 2007). UVR8 is a recently identified UV-B light photoreceptor believed to initiate regulatory changes in gene expression involved in UV-acclimation of plants in sunlight conditions (Fraikin et al., 2013). The mechanisms of light reception include conformational changes in the receptor chromophore molecule upon photoisomerization to initiate chromophoreprotein interactions, which transform light signals into biological signals capable of regulating light-inducible gene expression (Fraikin et al., 2013).

Plant responses to blue-light stimuli include phototropisms, suppression of stem elongation, chloroplast movements, stomatal regulation, and genetic expression (Baum et al., 1999). Phototropins (phot 1 and phot 2) are plasma membrane-bound serine/ threonine kinases that act as blue-light-activated regulators, which optimize photosynthesis and plant growth in low-light environments and can also reduce risk of photodamage (Christie, 2007; Fraikin et al., 2013). The xanthophyll cycle pigments (zeaxanthin, antheraxanthin, violaxanthin) in plants are vital for energy dissipation of excess absorbed radiant light energy. Under highlight stress, violaxanthin is rapidly and reversibly de-epoxidized into zeaxanthin via the intermediate antheraxanthin (DemmigAdams and Adams, 1996). The chemical transformation of violaxanthin to zeaxanthin is required for the conversion of photosystem II (PSII) from a state of efficient light harvesting to a state of high thermal energy dissipation, which is usually measured as a nonphotochemical quenching of chlorophyll fluorescence (Havaux et al., 2007). Zeaxanthin can modulate blue-light-dependent responses in plants and is believed to be an important photoreceptor for blue-lightactivated plant responses (Briggs and Huala, 1999; Kopsell et al., 2014; Tlałka et al., 1999).

Convincing scientific evidence now supports the association between dietary choices and chronic disease expression. The cornerstone of recommended dietary guidelines is increased consumption of fruit and vegetable crops, which provide human diets with many essential vitamins and minerals important for health maintenance. Vegetables also contain secondary metabolite phytochemicals, which provide benefits beyond normal health maintenance and nutrition and play active roles in chronic disease reductions (Kopsell and Kopsell, 2010). Stress is a term used to collectively describe numerous conditions 
that can have negative impacts on plant performance, such as drought, pathogen attack, drastic changes in temperature, high- or low-light conditions, and/or mineral nutrient imbalances. The production of antioxidant compounds within plants can increase or decrease in response to various forms of abiotic environmental stress (Kopsell et al., 2007, 2011). Capacities such as wavelength control, high light output, and low radiant heat emissions are making LEDs a popular alternative to traditional gas-filled or incandescent filament lamps in controlled environment plant production (Martineau et al., 2012; Massa et al., 2008; Morrow, 2008). Work in our program has been focused on identifying physiological plant responses to changing light quality and light quantity using LEDs. Of particular interest is the ability to modulate concentrations of nutritionally important secondary metabolites with applications of blue-light wavelengths.

\section{IMPACTS OF BLUE LIGHT ON THE ACCUMULATION OF NUTRITIONALLY IMPORTANT PIGMENTS}

Photochemical reactions of photosynthesis occur in the thylakoids when light energy is captured by chlorophyll and carotenoid pigments and converted into chemical energy. Within the thylakoid membranes of chloroplasts, carotenoids are in close association with specific protein complexes of PSI and PSII and function to help harvest light energy during photosynthesis and dissipate excess energy before photodamage occurs (Demmig-Adams and Adams, 1996; Kopsell et al., 2012). Biological activities attributed to chlorophyll derivatives consistent with cancer prevention include interference with oral absorption of carcinogens, antioxidant and antimutagenic activity, mutagen trapping, modulation of xenobiotic metabolism, and induction of apoptosis (Ferruzzi and Blakeslee, 2007; McQuistan et al., 2012). Chlorophyll $a$ and $b$ concentrations in kale (Brassica oleracea var. acephala) seedlings were highest when exposed to the narrowband LED wavelengths of 640 and $440 \mathrm{~nm}$, establishing a positive correlation between wavelength and chlorophyll accumulation in brassica seedlings (Lefsrud et al., 2008). Kopsell et al. (2014) demonstrated dramatic increases in chlorophyll pigment concentrations in sprouting broccoli (B. oleracea var. italica) microgreens grown under LED light when compared with fluorescent/incandescent lamps in controlled environments. In their study, the highest concentrations of chlorophyll pigments were found under $20 \%$ blue $(470 \mathrm{~nm}) / 80 \%$ red $(627 \mathrm{~nm})$ at an intensity of $250 \pm 10 \mu \mathrm{mol} \cdot \mathrm{m}^{-2} \cdot \mathrm{s}^{-1}$. However, Kopsell and Sams (2013) reported no impact on chlorophyll pigment concentrations in sprouting broccoli microgreens when the light environment was changed from $12 \%$ blue $(470 \mathrm{~nm}) / 88 \%$ red $(627 \mathrm{~nm})$ at 350 $\mu \mathrm{mol} \cdot \mathrm{m}^{-2} \cdot \mathrm{s}^{-1}$ to $100 \%$ blue at $41 \pm 2$ $\mu \mathrm{mol} \cdot \mathrm{m}^{-2} \cdot \mathrm{s}^{-1}$ for a 5 -d period before harvest, which may indicate blue light intensity is a determining factor in photochemical responses. Lin et al. (2013) measured no difference in chlorophyll pigment concentrations in mature lettuce (Lactuca sativa var. capitata) among red/blue, red/blue/white, and fluorescent lamp treatments at 210 $\mu \mathrm{mol} \cdot \mathrm{m}^{-2} \cdot \mathrm{s}^{-1}$. Li and Kubota (2009) supplemented cool white fluorescent light with different LED wavelengths to determine impacts of supplementation on phytochemical contents in 'Red Cross' baby leaf lettuce. These authors showed no impacts on chlorophyll concentrations in baby lettuce when fluorescent light treatments containing 23\% blue $(400-500 \mathrm{~nm}) / 52 \%$ green $(500-600$ $\mathrm{nm}) / 24 \%$ red $(600-700 \mathrm{~nm})$ at 300 $\mu \mathrm{mol} \cdot \mathrm{m}^{-2} \cdot \mathrm{s}^{-1}$ were compared with fluorescent light supplemented with blue LED light to achieve $55 \%$ blue $/ 31 \%$ green $/ 13 \%$ red at the same intensity. In a recent study, chlorophyll pigments in 30-d old Chinese kale (B. oleracea var. alboglabra) did not differ among the LED light treatments of $10 \%$ blue (470 $\mathrm{nm}) / 90 \%$ red $(627 \mathrm{~nm}), 20 \%$ blue $/ 80 \% \mathrm{red}$, and $40 \%$ blue $/ 60 \%$ red, but were significantly higher than kale grown under fluorescent/ incandescent light at similar light intensities of $250 \mu \mathrm{mol} \cdot \mathrm{m}^{-2} \cdot \mathrm{s}^{-1}$ (Kopsell et al., unpublished data). Chlorophyll $a$ and $b$ pigments in leaf tissue maximize light absorption at 663 and $642 \mathrm{~nm}$, respectively, and at 430 and $453 \mathrm{~nm}$, respectively (Lefsrud et al., 2008). Data may show leafy specialty crops produce higher concentrations of chlorophyll pigments in response to higher intensities of blue wavelengths in the light environment; however, responses may differ based on plant ontogeny and species genetics.

Carotenoids function to help harvest light energy, mostly in the blue-green wavelength range, which is transferred to the photosynthetic reaction centers. The conjugated double-bond systems of the carotenoids create light-absorbing chromophores, which result in the distinctive colors associated with carotenoid plant pigments (Cunningham and Gantt, 1998). Kopsell et al. (2014) demonstrated dramatic impacts on carotenoid pigment concentrations in sprouting broccoli microgreens grown under LED light when compared with fluorescent/incandescent lamps in controlled environments. In their study, the highest concentrations of $\beta$-carotene and lutein were found under the $20 \%$ blue $(470 \mathrm{~nm}) /$ $80 \%$ red $(627 \mathrm{~nm})$ light treatment, the highest concentrations of antheraxanthin and total integrated carotenoid pigments were found under the $20 \%$ blue $/ 70 \%$ red/ $10 \%$ green $(530 \mathrm{~nm})$ light treatment, and the highest concentrations of neoxanthin and violaxanthin were found under the fluorescent/ incandescent light treatment, with all treatments at the same intensity of $250 \pm 10$ $\mu \mathrm{mol} \cdot \mathrm{m}^{-2} \cdot \mathrm{s}^{-1}$. Neoxanthin is enzymatically converted from violaxanthin within the carotenoid biosynthetic pathway in plants. Cisisomers of both violaxanthin and neoxanthin are cleaved to form xanthoxin, a precursor to the important plant regulatory hormone abscisic acid (Nambara and Marion-Poll, 2005). Neoxanthin, a major carotenoid in green leafy vegetables, is reported to induce apoptosis in human prostate cancer cells in vitro (Asai et al., 2004). Li and Kubota (2009) showed that white light supplemented with blue light $(476 \mathrm{~nm})$ to produce 300 $\mu \mathrm{mol} \cdot \mathrm{m}^{-2} \cdot \mathrm{s}^{-1}$ resulted in significantly higher lettuce leaf tissue $\beta$-carotene and total xanthophyll carotenoids when compared with the white light control or white light supplemented with green light only $(526 \mathrm{~nm})$. Lin et al. (2013) reported no differences in total carotenoid concentrations in lettuce among red (660 $\mathrm{nm}) /$ blue $(454 \mathrm{~nm})$ LEDs, red/blue/white LEDs, or fluorescent light treatments at high photon flux $\left(210 \mu \mathrm{mol} \cdot \mathrm{m}^{-2} \cdot \mathrm{s}^{-1}\right)$. Moreover, Martineau et al. (2012) reported no differences in $\beta$-carotene, lutein, or neoxanthin in lettuce grown under natural light, natural light supplemented with high-pressure sodium lamps, or natural light supplemented with red $(640 \mathrm{~nm}) /$ blue $(450 \mathrm{~nm}) /$ white LEDs, with all light treatments at $\approx 190 \mu \mathrm{mol} \cdot \mathrm{m}^{-2} \cdot \mathrm{s}^{-1}$.

At low photon flux $\left(50 \mu \mathrm{mol} \cdot \mathrm{m}^{-2} \cdot \mathrm{s}^{-1}\right)$ for $10 \mathrm{~d}$ of exposure, carotenoid concentrations in buckwheat (Fagopyrum tataricum) sprouts were highest under white LEDs and did not differ when exposed to blue $(470 \mathrm{~nm})$ or red (660 nm) LED light (Tuan et al., 2013). Kopsell and Sams (2013) reported significantly higher shoot tissue $\beta$-carotene, violaxanthin, and total xanthophyll cycle pigments in sprouting broccoli microgreens when the light environment was changed from $12 \%$ blue $(470 \mathrm{~nm}) / 88 \%$ red $(627 \mathrm{~nm})$ at 350 $\mu \mathrm{mol} \cdot \mathrm{m}^{-2} \cdot \mathrm{s}^{-1}$ to $100 \%$ blue at $41 \pm 2$ $\mu \mathrm{mol} \cdot \mathrm{m}^{-2} \cdot \mathrm{s}^{-1}$ for a 5 -d period before harvest. Additionally, Gangadhar et al. (2012) showed that total carotenoid pigment concentrations in leaf tissues of chili pepper (Capsicum annuum) seedlings were higher under LED lighting treatments than for fluorescent light at low photon flux (70 umol $\left.\cdot \mathrm{m}^{-2} \cdot \mathrm{s}^{-1}\right)$. Results from the study also showed that blue $(460 \mathrm{~nm})$ LEDs resulted in significantly higher leaf tissue carotenoids in the pepper leaves as compared with only red $(660 \mathrm{~nm})$ or red/blue $(1: 1 \mathrm{ratio})$. Similar to chlorophyll pigments, concentrations of individual and total carotenoid pigments appear to be influenced by blue wavelengths in the light environment and also by plant ontogeny and species genetics.

\section{IMPACTS OF BLUE LIGHT ON THE ACCUMULATION OF NUTRITIONALLY IMPORTANT GLUCOSINOLATES}

Glucosinolates are sulfur-containing secondary metabolites present in brassica species (Stoewsand, 1995). Glucosinolates have no identifiable primary function in plants, but are theorized to protect against predation and pathogens, as well as to act as sulfur storage reserves (Zukalová et al., 2002). Following cellular disruption, glucosinolates are enzymatically decomposed by the enzyme myrosinase and produce mixtures of volatile and nonvolatile compounds including isothiocyanates, thiocyanates, and nitriles possessing anticarcinogenic properties (Fahey et al., 
1997; Heaney and Fenwick, 1980; Stoewsand, 1995).

Previous research has demonstrated that the light environment can impact glucosinolate concentrations in specialty crops (Charron and Sams, 2004; Kopsell and Sams, 2013; Lefsrud et al., 2008). Kopsell et al. (2014) showed the potential to manipulate glucosinolate concentrations through changes in light quality. In that study, LED light treatments of $5 \%$ blue $(470 \mathrm{~nm}) / 95 \%$ red $(630$ $\mathrm{nm}), 5 \%$ blue $/ 85 \%$ red $/ 10 \%$ green $(530 \mathrm{~nm})$, and $20 \%$ blue $/ 80 \%$ red at an intensity of $250 \pm$ $10 \mu \mathrm{mol} \cdot \mathrm{m}^{-2} \cdot \mathrm{s}^{-1}$ cause significantly higher individual and total aliphatic and total indole glucosinolates than broccoli microgreens grown under the fluorescent/incandescent light treatment. Kopsell and Sams (2013) reported significantly higher shoot tissue total aliphatic and aromatic glucosinolates in sprouting broccoli microgreens when the light environment was changed from $12 \%$ blue $(470 \mathrm{~nm}) / 88 \%$ red $(627 \mathrm{~nm})$ at 350 $\mu \mathrm{mol} \cdot \mathrm{m}^{-2} \cdot \mathrm{s}^{-1}$ to $100 \%$ blue at $41 \pm 2$ $\mu \mathrm{mol} \cdot \mathrm{m}^{-2} \cdot \mathrm{s}^{-1}$ for a 5 -d period before harvest. In that study, the short-duration blue-light treatment before harvest significantly increased individual glucosinolates of epiprogoitrin, glucoraphanin, and gluconasturtiin in sprouting broccoli microgreens. Lefsrud et al. (2008) found higher sinigrin (an aliphatic glucosinolate) concentrations in kale grown under LEDs at individual wavelengths of $730 \mathrm{~nm}\left(15.2 \mu \mathrm{mol} \cdot \mathrm{m}^{-2} \cdot \mathrm{s}^{-1}\right)$ and $640 \mathrm{~nm}$ $\left(253.3 \mu \mathrm{mol} \cdot \mathrm{m}^{-2} \cdot \mathrm{s}^{-1}\right)$, but could not detect sinigrin in the kale tissues following a 7-d exposure to $440 \mathrm{~nm}\left(10.6 \mu \mathrm{mol} \cdot \mathrm{m}^{-2} \cdot \mathrm{s}^{-1}\right)$. An earlier study showed that blue, green, and white colored mulches reflected $25 \%, 7 \%$, and $41 \%$ of incoming solar radiation, respectively, in the blue $(450 \pm 5 \mathrm{~nm})$ wavelengths impacted glucosinolates in the root crop turnip (Brassica rapa var. rapa). Total glucosinolate concentrations in turnip were significantly higher for plants receiving higher percentages of reflected blue light from blue colored mulches (Antonious et al., 1996). Glucosinolates classes are divided based on amino acids side chain derivatives. Aliphatic glucosinolates are derived from Ala, Leu, Ile, Val, and Met, aromatic glucosinolates are derived from Phe or Tyr, and indole glucosinolates are derived from Trp (Sønderby et al., 2010). It is possible that glucosinolates side chain elongation and modifications through amino acid metabolism are impacted by narrow-band wavelengths. Blue wavelengths in the light environment can influence glucosinolate concentrations, with the impacts affected by intensity of blue light, plant ontogeny, and species genetics.

\section{IMPACTS OF BLUE LIGHT ON THE ACCUMULATION OF NUTRITIONALLY IMPORTANT MINERAL ELEMENTS}

The blue light receptor phototropins (phot 1 and phot 2) regulate hypocotyl phototropisms in a fluence-dependent manner, with phot 1 functioning at both low $\left(0.01-1 \mu \mathrm{mol} \cdot \mathrm{m}^{-2} \cdot \mathrm{s}^{-1}\right)$ and high $\left(>1 \mu \mathrm{mol} \cdot \mathrm{m}^{-2} \cdot \mathrm{s}^{-1}\right)$ fluence rates and phot 2 functioning at only high fluence rates (Inada et al., 2004; Sakai et al., 2001; Zhao et al., 2013). The phototropins confer their effects through changes in $\mathrm{Ca}^{2+}$ ion homeostasis (Zhao et al., 2013) and mobilize $\mathrm{Ca}^{2+}$ in response to blue light. Under low blue light, phot 1 controls the flux of $\mathrm{Ca}^{2+}$ through plasma membrane channels; whereas, under high blue light, phot 2 causes increases in cytosolic $\mathrm{Ca}^{2+}$ through release from internal stores and through plasma membrane channels (Harada and Shimazaki, 2007). Blue light exposure can also cause significant changes in guard cell membrane transport activity through variations in $\mathrm{K}^{+}$and $\mathrm{H}^{+}$fluxes and corresponding impacts on $\mathrm{pH}$ conditions (Babourina et al., 2002). Even though $\mathrm{Ca}^{2+}$ acts as an important secondary messenger crucial for cellular responses to environmental stimuli, the ability of blue light to influence mineral element movements through phototropin functioning is probable.

Kopsell and Sams (2013) reported significantly higher shoot tissue concentrations of $\mathrm{P}, \mathrm{K}, \mathrm{Mg}, \mathrm{Ca}, \mathrm{S}, \mathrm{B}, \mathrm{Cu}, \mathrm{Fe}, \mathrm{Mn}, \mathrm{Mo}, \mathrm{Na}$, and $\mathrm{Zn}$ in sprouting broccoli microgreens when the light environment was changed from $12 \%$ blue $(470 \mathrm{~nm}) / 88 \%$ red $(627 \mathrm{~nm})$ at 350 $\mu \mathrm{mol} \cdot \mathrm{m}^{-2} \cdot \mathrm{s}^{-1}$ to $100 \%$ blue at $41 \pm 2$ $\mu \mathrm{mol} \cdot \mathrm{m}^{-2} \cdot \mathrm{s}^{-1}$ for a $5-\mathrm{d}$ period before harvest. Further, Kopsell et al. (2014) showed significantly higher concentrations of tissue $\mathrm{Ca}, \mathrm{K}$, $\mathrm{Mg}, \mathrm{P}, \mathrm{S}, \mathrm{B}, \mathrm{Cu}, \mathrm{Fe}, \mathrm{Mn}, \mathrm{Mo}$, and $\mathrm{Zn}$ in broccoli microgreens grown under the higher blue LED light treatments of $20 \%$ blue ( 470 $\mathrm{nm}) / 80 \%$ red $(630 \mathrm{~nm})$ and $20 \%$ blue $/ 70 \%$ $\mathrm{red} / 10 \%$ green $(530 \mathrm{~nm})$ at an intensity of $250 \pm 10 \mu \mathrm{mol} \cdot \mathrm{m}^{-2} \cdot \mathrm{s}^{-1}$, when compared with a fluorescent/incandescent light treatment at the same intensity. The impacts of blue light on stomatal opening and membrane transport activity may be the underlying cause for such increases in macronutrient and micronutrient accumulations in the broccoli microgreen tissues, but exact mechanisms remain unclear (Kopsell et al., 2014; Kopsell and Sams, 2013).

Specialized plant photoreceptors sense and react to changing light quality and quantity through developmental and physiological responses. Light interception causes photoisomerization of chromophore complexes, which ultimately leads to gene regulation of specific biochemical pathways. Phototropin blue-light receptors control such plant responses as phototropisms, suppression of stem elongation, chloroplast movements, and stomatal regulation. Downstream regulation from blue-light stimuli may also include metabolite fluxes in nutritionally important plant secondary metabolic pathways. Research into the photomorphological impacts of blue wavelengths using LEDs has shown responses to be determined, in part, by photon flux intensity, photoperiod, plant ontogeny, and species genetics. With all of these interacting factors, much more information is needed before producers can successfully manage specific wavelengths in the light environment to maximize the nutritional functionality of specialty vegetable crops.

\section{Literature Cited}

Antonious, G.F., M.J. Kasperbauer, and M.E. Byers. 1996. Light reflected from colored mulches to growing turnip leaves affects glucosinolate and sugar contents of edible roots. Photochem. Photobiol. 64(3):605-610.

Asai, A., M. Terasaki, and A. Nagao. 2004. An epoxide-furanoid rearrangement of spinach neoxanthin occurs in the gastrointestinal tract of mice and in vitro: Formation and cytostatic activity of neochrome stereoisomers. J. Nutr. 134(9):2237-2243.

Babourina, O., I. Newman, and S. Shabala. 2002. Blue light-induced kinetics of $\mathrm{H}^{+}$and $\mathrm{Ca}^{2+}$ fluxes in etiolated wild-type and phototropinmutant Arabidopsis seedlings. Proc. Natl. Acad. Sci. USA 99(4):2433-2438.

Baum, G., J.C. Long, G.I. Jenkins, and A.J. Trewavas. 1999. Stimulation of the blue light phototropic receptor NPH1 causes a transient increase in cytosolic $\mathrm{Ca}^{2+}$. Proc. Natl. Acad. Sci. USA 96(23):13554-13559.

Briggs, W.R. and J.M. Christie. 2002. Phototropins 1 and 2: Versatile plant blue-light receptors. Trends Plant Sci. 7(5):204-210.

Briggs, W.R. and E. Huala. 1999. Blue-light photoreceptors in higher plants. Annu. Rev. Cell Biol. 15:33-62.

Charron, C.S. and C.E. Sams. 2004. Glucosinolate content and myrosinase activity in rapidcycling Brassica oleracea grown in a controlled environment. J. Amer. Soc. Hort. Sci. 129:321330 .

Chaves, I., R. Pokorny, M. Byrdin, N. Hoang, T. Ritz, K. Brettel, L.O. Essen, G.T.J. van der Horst, A. Batschauer, and M. Ahmad. 2011. The cryptochromes: Blue light photoreceptors in plants and animals. Annu. Rev. Plant Biol. 62:335-364.

Christie, J.M. 2007. Phototropin blue-light receptors. Annu. Rev. Plant Biol. 58:21-45.

Cunningham, F.X. and E. Gantt. 1998. Genes and enzymes of carotenoid biosynthesis in plants. Annu. Rev. Plant Physiol. Plant Mol. Biol. 49:577-583.

Demmig-Adams, B. and W.W. Adams, III. 1996. The role of xanthophyll cycle carotenoids in the protection of photosynthesis. Trends Plant Sci. 1(1):21-26.

Fahey, J.W., Y. Zhang, and P. Talalay. 1997. Broccoli sprouts: An excellent rich source of inducers of enzymes that protect against chemical carcinogens. Proc. Natl. Acad. Sci. USA 94(19):10367-10372.

Ferruzzi, M.G. and J. Blakeslee. 2007. Digestion, absorption, and cancer preventative activity of dietary chlorophyll derivatives. Nutr. Rev. 27(1): 1-12.

Fraikin, G.Y., M.G. Strakhovskaya, and A.B. Rubin. 2013. Biological photoreceptors of light-dependent regulatory processes. Biochemistry (Mosc.) 78(11):1238-1253.

Gangadhar, B.H., R.K. Mishra, G. Pandian, and S.W. Park. 2012. Comparative study of color, pungency, and biochemical composition in chili pepper (Capsicum annuum) under different light-emitting diode treatments. HortScience 47:1729-1735.

Harada, A. and K. Shimazaki. 2007. Phototropins and blue light-dependent calcium signaling in higher plants. Photochem. Photobiol. 83(1): 102-111.

Havaux, M., L. Dall'Osto, and R. Bassi. 2007. Zeaxanthin has enhanced antioxidant capacity with respect to all other xanthophylls in Arabidopsis leaves and functions independent of binding to PSII antennae. Plant Physiol. 145(4):1506-1520. 
Heaney, R.K. and G.R. Fenwick. 1980. The analysis of glucosinolates in Brassica species using gas chromatography. Direct determination of the thiocyanate precursors, glucobrassicin and neoglucobrassicin. J. Sci. Food Agr. 31(6): 593-599.

Inada, S., M. Ohgishi, T. Mayama, K. Okada, and T. Sakai. 2004. RPT2 is a signal transducer involved in phototropic response and stomatal opening by association with phototropin 1 in Arabidopsis thaliana. Plant Cell 16(4):887-896.

Kopsell, D.A., G.R. Armel, K. Abney, J.J. Vargas, J.T. Brosnan, and D.E. Kopsell. 2011. Leaf tissue carotenoids and chlorophyll fluorescence parameters differ among sweet corn genotypes with differential herbicide sensitivity. Pestic. Biochem. Physiol. 99(2):194-199.

Kopsell, D.A. and D.E. Kopsell. 2010. Carotenoids in vegetables: Biosynthesis, occurrence, impacts on human health, and potential for manipulation, p. 645-662. In: R. Ross and V.R. Preedy (eds.). Bioactive food in promoting health: Fruits and vegetables. Elsevier, St. Louis, MO.

Kopsell, D.A., N.I. Pantanizopoulos, C.E. Sams, and D.E. Kopsell. 2012. Shoot tissue pigment levels increase in 'Florida Broadleaf' mustard (Brassica juncea L.) microgreens following high light treatment. Sci. Hort. 140:96-99.

Kopsell, D.A. and C.E. Sams. 2013. Increases in shoot tissue pigments, glucosinolates, and mineral elements in sprouting broccoli after exposure to short-duration blue light from light-emitting diodes. J. Amer. Soc. Hort. Sci. 138:31-37.

Kopsell, D.A., C.E. Sams, T.C. Barickman, and R.C. Morrow. 2014. Sprouting broccoli accumulate higher concentrations of nutritionally important metabolites under narrow-band light-emitting diode lighting. J. Amer. Soc. Hort. Sci. 139:469-477.

Kopsell, D.A., C.E. Sams, C.S. Charron, W.M. Randle, and D.E. Kopsell. 2007. Kale carotenoids remain stable while glucosinolates and flavor compounds respond to changes in selenium and sulfur fertility. Acta Hort. 744:303309.

Lefsrud, M.G., D.A. Kopsell, and C.E. Sams. 2008. Irradiance from distinct wavelength lightemitting diodes affects secondary metabolites in kale. HortScience 43:2243-2244.

Li, Q. and C. Kubota. 2009. Effects of supplemental light quality on growth and phytochemicals of baby leaf lettuce. Environ. Expt. Bot. 67(1):59-64.

Lin, K.H., M.Y. Huang, W.D. Huang, M.H. Hsu, Z.W. Yang, and C.M. Yang. 2013. The effects of red, blue, and white light-emitting diodes on the growth, development, and edible quality of hydroponically grown lettuce (Lactuca sativa L. var. capitata). Sci. Hort. 150:86-91.

Martineau, V., M.G. Lefsrud, M. Tahera Naznin, and D.A. Kopsell. 2012. Comparison of supplemental greenhouse lighting from light emitting diode and high pressure sodium light treatments for hydroponic growth of Boston lettuce. HortScience 47:477-482.

Massa, G.D., H.H. Kim, R.M. Wheeler, and C.A. Mitchell. 2008. Plant productivity in response to LED lighting. HortScience 43:1951-1956.

McCree, K.J. 1972. Test of current definitions of photosynthetically active radiation against leaf photosynthesis data. Agr. Meteorol. 10:443-453.

McCree, K.J. 1973. The measurement of photosynthetically active radiation. Sol. Energy 15:83-87.

McQuistan, T.J., M.T. Simonich, M.M. Pratt, C.B. Pereira, J.D. Hendricks, R.H. Dashwood, D.E. Williams, and G.S. Bailey. 2012. Cancer chemoprevention by dietary chlorophylls: A 12,000-animal dose-dose matrix biomarker and tumor study. Food Chem. Toxicol. 50(2): 341-352.

Morrow, R.C. 2008. LED lighting in horticulture. HortScience 43:1947-1950.

Nambara, E. and A. Marion-Poll. 2005. Abscisic acid biosynthesis and catabolism. Annu. Rev. Plant Biol. 56:156-185.
Sakai, T., T. Kagawa, M. Kasahara, T.E. Swartz, J.M. Christie, W.R. Briggs, W. Wada, and K. Okada. 2001. Arabidopsis nph1 and npl1: Blue light receptors that mediate both phototropism and chloroplast relocation. Proc. Natl. Acad. Sci. USA 98(12):6969-6974.

Smith, H. 1982. Light quality, photoperception, and plant strategy. Annu. Rev. Plant Physiol. Plant Mol. Biol. 33:481-518.

Sønderby, I.E., F. Geu-Flores, and B.A. Halkier. 2010. Biosynthesis of glucosinolates - gene discovery and beyond. Trends Plant Sci. 15(5): 283-290.

Stoewsand, G.S. 1995. Bioactive organosulfur phytochemicals in Brassica oleracea vegetables a review. Food Chem. Toxicol. 33(6):537543.

Tlałka, M., M. Runquist, and M. Fricker. 1999. Light perception and the role of the xanthophyll cycle in blue-light-dependent chloroplast movements in Lemna trisulca L. Plant J. 20(4):447459.

Tuan, P.A., A.A. Thwe, Y.B. Kim, J.K. Kim, S. Kim, S. Lee, S. Chung, and S.U. Park. 2013. Effects of white, blue, and red light-emitting diodes on carotenoid biosynthetic gene expression levels and carotenoid accumulation in sprouts of tartary buckwheat (Fagopyrum tataricum Gaertn.). J. Agr. Food Chem. 61(50): 12356-12361.

Vierstra, R.D. and J. Zhang. 2011. Phytochrome signaling: Solving the Gordian knot with microbial relatives. Trends Plant Sci. 16(8):417426.

Zhao, X., Y.L. Wang, X.R. Qiao, J. Wang, L.D. Wang, C.S. Xu, and X. Zhang. 2013. Phototropins function in high-intensity blue lightinduced hypocotyl phototropism in Arabidopsis by altering cytosolic calcium. Plant Physiol. 162(3):1539-1551.

Zukalová, H., J. Vašák, D. Nerad, and P. Štranc. 2002. The role of glucosinolates of Brassica genus in the crop system. Rostlinná Výroba 48(4):181-189. 